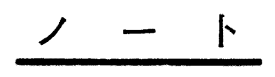

\title{
シロザケ内臓部脂質の脂肪酸組成
}

\author{
日下兵爾 - 滝川光広 ・坪内寿彦・太田静行 \\ 北里大学水産学部 (岩手県気仙郡三陸町)
}

\section{Fatty Acid Composition of Lipids in the Viscera of Chum Salmon}

Hyoji Kusaka, Mitsuhiro Takigawa, Toshihiko Tsubouchi, and Shizuyuki OHтA

School of Fishery Science, Kitasato University (Sanriku-cho, Kesen-gun, Iwate-ken)

The fatty acid composition of lipids in the viscera of chum salmon, Oncorhynchus keta was exa= mined by GLC, before and after fractionation into polar and nonpolar lipids.

The contents of polyunsaturated fatty acid, such as $20: 5$ and $22: 6$, were high in chum salmon viscera lipids.

The compositional percentages of the fatty acids of lipids in the examined viscera, liver, heart, kidney, genital gland, digestive organs differed somewhat.

\section{1 緒言}

シロザケ Oncorhynchus keta は我が国ではもっとも 一般的なサケであり，広く食用にされている。シロザケ は新巻きなどに加工され，その生産量は近年大幅に増加 しているが, 加工に際して, 内臟部は除去され, 廃棄物 となっている。

このシロザケの内臟部の有効な利用を考えるに当たっ て, その一環として, 内臓部脂質の脂肪酸組成を調べ た。シロザケの脂質については，肉部に関しては既にか なりの報告があり 12 6)，卵についても報告されている7 が, 内藏全般については報告がなく, とくに脂肪酸組成 については報告が見当たらない。

それで，我々は岩手県三陸町近辺の海に産卵回帰した シロザケを試料として，その内藏全般と各臟器につい て, それらの脂質含量と脂質の脂肪酸組成を測定した。

\section{2 実験方法及び結果}

\section{$2 \cdot 1$ 試料}

本実験の試料には岩手県三陸町の浦浜川に昭和 58 年 12 月 17 日に遡河し漁獲されたシロザケを用い, 浦浜川 鮭鱒孵化場において分離された内臟を用いた。

各内臟の脂質抽出の試料としたものは, 雄は体重 3.90 $\mathrm{kg}$ (体長 $68 \mathrm{~cm}$ ，以下括弧内は体長），1.78 kg $(53.5$ $\mathrm{cm}), 4.4 \mathrm{~kg}(71 \mathrm{~cm}), 1.66 \mathrm{~kg}(52 \mathrm{~cm})$, 雌は卵除去後 の体重 $2.82 \mathrm{~kg}(65 \mathrm{~cm}), 2.82 \mathrm{~kg}(65.5 \mathrm{~cm}), 3.15 \mathrm{~kg}$ $(67 \mathrm{~cm}), 4.8 \mathrm{~kg}(79 \mathrm{~cm})$ のもので, 各藏器に分離した 後, 各藏器をあわせて脂質抽出の試料とした。
全内藏の脂質抽出の試料としたものは, 雄は $0.93 \mathrm{~kg}$ $(46.5 \mathrm{~cm}), 1.77 \mathrm{~kg}(52 \mathrm{~cm})$, 雌は卵除去後の体重 1.53 $\mathrm{kg}(55.5 \mathrm{~cm}), 1.77 \mathrm{~kg}(53.5 \mathrm{~cm})$ のものである。 各臟器の魚体に対する割合を Table-1 に示す。

Table-1 Weight of viscera and lipid contents $(\%)$ of each organ of chum salmon

\begin{tabular}{|c|c|c|c|c|}
\hline \multirow{2}{*}{ Viscera } & \multicolumn{2}{|c|}{ Organs $(\%)$} & \multicolumn{2}{|c|}{ Lipid (\%) } \\
\hline & Male & Female & Male & Female \\
\hline Total viscera & 4.5 & 4.0 & 2.5 & 2.5 \\
\hline $\begin{array}{l}\text { Stomach, pyloric } \\
\text { caecum, intestine }\end{array}$ & 1.3 & 1.0 & 2.5 & 2.5 \\
\hline Kidney & 1.0 & 0.8 & \multicolumn{2}{|c|}{$\widetilde{3.0}$} \\
\hline Heart & & & \multicolumn{2}{|c|}{$\widetilde{2.1}$} \\
\hline Liver & 2.0 & 1.8 & \multicolumn{2}{|c|}{$\overbrace{3.6}$} \\
\hline Testis & 4.1 & - & 2.4 & - \\
\hline Ovary & - & 19.6 & - & 9.0 \\
\hline
\end{tabular}

\section{$2 \cdot 2$ 脂質の抽出}

シロザケの各内藏から脂質の抽出にはホルチ法帛を用 いた。すなわち，シロザケの全内臟及び各内臓ごとに分 離した後, 細切し, これを原料としてクロロホルムーメ タノール (2:1) 混液による抽出を行った。このとき得 られた脂質量を各臓器 $100 \mathrm{~g}$ あたりに換算して, Table1 に示す。

\section{$2 \cdot 3$ 各脂質の脂肪酸組成の測定}

$2 \cdot 3 \cdot 1$ 各脂質脂肪酸のメチルエステル化

各脂質のメチルエステル化には, 日本油化学協会編, 基準 油脂分析 試験法， 2.4.20.2-77 により，三フッ化 
Table-2 Fatty acid composition (\%) of lipids of visceras of chum salmon.

\begin{tabular}{c|c|r|r|r|r|r|r|r}
\hline Fatty acid & $\begin{array}{l}\text { Stomach, } \\
\text { pyloric } \\
\text { caecum, } \\
\text { intestine }\end{array}$ & Kidney & Heart & Liver & Testis & Ovary & \multicolumn{2}{|c}{ Total viscera } \\
\hline $14: 0$ & 1.8 & 1.6 & 1.3 & 1.6 & 2.0 & 4.5 & 2.0 & Male \\
$15: 0$ & 0.4 & & & & & & 0.4 & 0.2 \\
$16: 0$ & 18.5 & 18.1 & 16.4 & 19.4 & 18.0 & 9.2 & 13.9 & 16.6 \\
$16: 1$ & 2.3 & 4.4 & 1.8 & 3.3 & 3.3 & 8.2 & 2.7 & 2.4 \\
$17: 0$ & & & & & & & 0.6 & -1 \\
$18: 0$ & 5.9 & 4.2 & 4.0 & 4.2 & 3.3 & 4.9 & 5.1 & 3.9 \\
$18: 1$ & 14.4 & 16.4 & 11.4 & 14.4 & 18.3 & 23.1 & 16.2 & 14.3 \\
$18: 2$ & 1.0 & 1.4 & 0.9 & 1.0 & 1.2 & 2.3 & 1.0 & 1.2 \\
$18: 3+20: 1$ & 2.2 & 1.6 & 3.5 & 2.3 & 1.9 & 3.6 & 2.1 & 2.2 \\
$20: 2$ & & & & & & 2.0 & 0.4 & 0.3 \\
$20: 4+22: 1$ & 4.6 & 3.1 & 4.3 & 4.2 & 2.6 & 1.2 & 4.1 & 4.5 \\
$20: 5$ & 6.8 & 10.0 & 7.2 & 12.0 & 17.7 & 13.0 & 10.5 & 12.2 \\
$22: 5$ & 4.7 & 3.8 & 4.5 & 5.4 & 3.2 & 5.9 & 4.2 & 3.6 \\
$22: 6$ & 28.3 & 28.9 & 38.3 & 24.9 & 17.1 & 16.7 & 26.8 & 24.0 \\
\hline Others & & & & & & $24: 1$ & $20: 0$ & \\
\hline
\end{tabular}

ホウ素ーメタノール法を用いた。

$2 \cdot 3 \cdot 2$ 脂肪酸メチルエステルのガスクロマトグラフ 1ー

上記の方法によって調製した脂肪酸メチルエステルに ついて, ガスクロマトグラフィー (GLC) を行い, 各試 料の脂肪酸組成を調べた。

GLC は柳本製作所製 Yanaco G180 型（FID 付き） を用い，カラムは $3 \mathrm{~mm} \phi \times 2.25 \mathrm{~m}$ のステンレススチー ル製：カラム充てん剤は 5\% SILAR-10C Chromosorb WAW DMCS $80 / 100$ mesh カラム温度は $150 \sim 230^{\circ} \mathrm{C}$, $2^{\circ} \mathrm{C} / \mathrm{min}$ の昇温, 注大口温度 $270^{\circ} \mathrm{C}$, キャリヤーガス $\mathrm{N}_{2}$, $20 \mathrm{ml} / \mathrm{min}$ の条件で行った。

各脂肪酸は, 常法により標品の保持時間との比較, 炭 素数と保持時間の対数值との直線関係などから同定し た。また, 定量の際の面積計算と百分率の算出には, シ ステムインスッルメント社製インテグレーター（SIC Model 5000 E) を使用した。

$2 \cdot 3 \cdot 3$ 各脂質の脂肪酸組成

シロザケの各臟器の脂質の脂肪酸組成の測定結果を Table-2 に示す。

\section{3 実験結果の考察}

\section{$3 \cdot 1$ シロザケ内臟の脂質含量}

シロザケ内臟の脂質量は Table-1にみられるように, 背肉部( ${ }^{6)}$ に比べると量が多い。雌雄では量に大きな相違 はみられない。

シロザケ背肉部の脂質は液状で流動性があった 内臟部脂質は固型で流動性がなかった。内臟部脂質の脂 肪酸組成は Table-2 に示されるように不飽和脂肪酸が 多いにもかかわらず固型であるのは, 背肉部と内臟部脂
質を構成する脂質組成に差異があるためと考えられ，極 性脂質と中性脂質の比率などについては別に測定する予 定である。

\section{$3 \cdot 2$ シロザケ内臟脂質の脂肪酸組成}

シロザケ内臟脂質の脂肪酸組成は Table-2 に示され るように, 雌雄を比較すると主要脂肪酸の $16: 1,18$ : 1, $20: 5,22: 6$ その他で 1 3\% の差がみられる。

これは雄の場合は生殖線をも含めた総内臓脂質であ り，雌の場合は生殖線を含めずに試料としたためである と考えられる。背肉部脂質の脂肪酸組成 ${ }^{2)}$ と比較すると かなりの相違がみられる。

Table-2 によると, 各臟器脂質の脂肪酸組成にもか なりの相違がみられる。たとえば心臓脂質では $22: 6$ 酸が著しく量が多いが，これが一般的な特徵であるか否 かについては後に別に試料を得て調べる予定である。

本実験に際し, 種々御援助いただいた株式会社学習研究社植 物工学研究所, シロザタ内臟を試料として用意するに当たって 御協力いただいた三陸町浦浜川鮭鱒餒化場の千葉哲男氏に厚く お礼申し上げる。

(昭和 59 年 11 月 29 日受理)

\section{文献}

1）座間宏一，五十嵐久尚，日水誌， 18，618 (1953)；19, 1087 (1953)

2）宇野 勉, 徳永俊夫, 中村全良, 北水試報告, 14, 89 (1956)

3）高橋玄夫，金子博実，一杉哲郎，北大水月報，33 (12), 1 (1976)

4) 新間弥一郎, 田口脩子, 日水誌, 30, 179 (1964)

5) 羽田野六男, 高間浩蔵, 小島博文, 座間宏一, 日水誌, 49, 213 (1983)

6) 日下兵爾, 滝川光広, 坪内寿彦, 太田静行, 上村俊一, 油化学, 34, 386 (1985)

7) 太田静行, 調理科学 16, 13 (1983)

8）藤野安彦, “脂質分析法入門”, 学会出版センター (1978) p. 42 